\title{
OPTIMIZATION OF NUCLEIC ACID BINDING TO MAGNETIC PARTICLES WITH THE AIM OF DETECTION OF DANGEROUS VIRUSES
}

\author{
1,2Dominik BANÁŠ, ${ }^{2}$ Ondřej RYCHLÝ, ${ }^{3}$ Stefano SALMISTRARO, ${ }^{2,4,5}$ Ahmet Davut AKSU, \\ ${ }^{6}$ Miroslava KRZYŽÁNKOVÁ, ${ }^{2,4}$ Rene KIZEK \\ ${ }^{1}$ Department of Biochemistry, Masaryk University, Brno, Czech Republic, EU, dominik.banass@gmail.com \\ ${ }^{2}$ Department of Research and Development, ENVI-ECO-NANOLIFE, s.r.o., Prague, Czech Republic, EU \\ ${ }^{3}$ University of Bologna, Ozzano dell' Emilia - Bologna, Italy, EU \\ ${ }^{4}$ Department of Pharmacology and Toxicology, Faculty of Pharmacy, Masaryk University, Brno, \\ Czech Republic, EU \\ ${ }^{5}$ Bezmialem Vakıf Üniversites, Istanbul, Turkey \\ ${ }^{6}$ Veterinary Research Institute, Brno, Czech Republic, EU, krzyzankova@vri.cz
}

https://doi.org/10.37904/nanocon.2020.3748

\begin{abstract}
African Swine Fever Virus (ASFV) is a DNA virus of the Asfivirus genus of the Asfarviridae family that is found in blood, body fluids, and internal organs. ASFV was described more than 40 years ago. This virus spreads pandemically and the mortality rate of the virus-related disease ranges from 90 to $100 \%$. The aim of this study was to propose the detection of specific nucleic acid of ASFV using electrochemical hybridization biosensor. Determination of DNA was conducted by AdTSV DPV a CV (potential $0 \mathrm{~V}$, end potential $-1.8 \mathrm{~V}$, step potential $5 \mathrm{mV}$, modulation amplitude $25 \mathrm{mV}, 0.2 \mathrm{M}$ acetate buffer $\mathrm{pH}$ 5.0). The volume of analysed sample was $10 \mu \mathrm{L}$. CV signals CA $(\log -0.0373 x, r$ 0.99, Ep $-1.30 \mathrm{~V})$ and P peak $(\log -0.0801 x, r 0.99, E p-1.52 \mathrm{~V})$ were observed. To increase the sensitivity, a modification of ODN with CdTe was proposed. The CdTe signal was observed around the potential of $-0.56 \mathrm{~V}$ and for modified ODNs the signal was $-0.58 \mathrm{~V}$. SPION were prepared to capture DNA. The interaction of DNA (PCR fragment, $280 \mathrm{bp}$ ) with SPION was very fast within $30 \mathrm{~s}$. The technique will be further used for a microfluidic system.
\end{abstract}

Keywords: Emergency biosensor, nucleic acid, oligonucleotide, quantum dots, super paramagnetic nanoparticle

\section{INTRODUCTION}

Viruses (Ebola virus, flu virus etc.) cause a variety of dangerous diseases which can be life-threatening for animals and humans. Highly infectious coronavirus pandemic is an obvious evidence of this fact [1]. For purpose of development of suitable curative and diagnostic approaches, new experimental model systems are searched. African swine fever (ASF) is very serious disease which affects wild and domestic pigs (Suidae) [2,3]. ASF firstly appeared in Sub-Saharan area of Africa [4] and afterwards spread via the Transcaucasian area to Russia, China and states of European Union [5-8]. ASF has not been confirmed in Pacific area yet. Not only local people are concerned that this disease will soon penetrate to this area because of people travelling and beef import from countries with ASF occurrence. Epidemiologic situation of transfer of ASF virus (ASFV) shows that, in 2019, there were 1894 infection outbreaks among domestic pigs in European states. The most serious situation was in Romania (1728 outbreaks). Small breeding were affected the most. In 2020, big breeding in Romania and Bulgaria were also endangered. The situation is completely out of control in several states in terms of wild pigs (Poland and Balkan states are most affected). Besides Europe, the epidemic gains strength in Southwest Asia (China, Bali, Indonesia, Laos, The Philippines, Vietnam and Cambodia) [9]. 
As it is seen from previous knowledge, the instruments for reliable and fast detection of ASFV are necessary. For the fast diagnostics directly in a place of infection outbreak, the portable detectors based on biomolecules (enzyme, protein, peptide, antibody, nucleic acid etc.) can be very helpful. Biosensors can use a plethora of methods based on selective and specific bonds with searched analyse (in our case - a virus or a part of virus). The huge advantage of suggested devices is their relatively small operating and acquisition price $[10,11]$. Biosensors can be differently organised based on the type of biorecognition element and transducer (piezoelectric, thermal, optical, electrical, and electrochemical). Electrochemical detection of nucleic acid is based on redox abilities of their nucleic bases [10]. In 1986 Irena Postbielgová with Emil Paleček suggested a technique of adsorptive transfer (AdTSV), when nucleic acid, in a form of small drop (3-10 $\mu$ l) is transferred and accumulated on electrode surface [12-14]. The cornerstone of design of biosensor for rapid analysis of ASFV was suggested. The described AdTSV DPV was used for studying of oligonucleotides KING R and KING $\mathrm{F}$, which are complementary to viral DNA and their interaction with CdTe quantum dots as well [15]. The aim of this project is to receive information about detection of nucleic acid bound on surface of magnetic nanoparticles with use of electrochemistry (Figure 1).

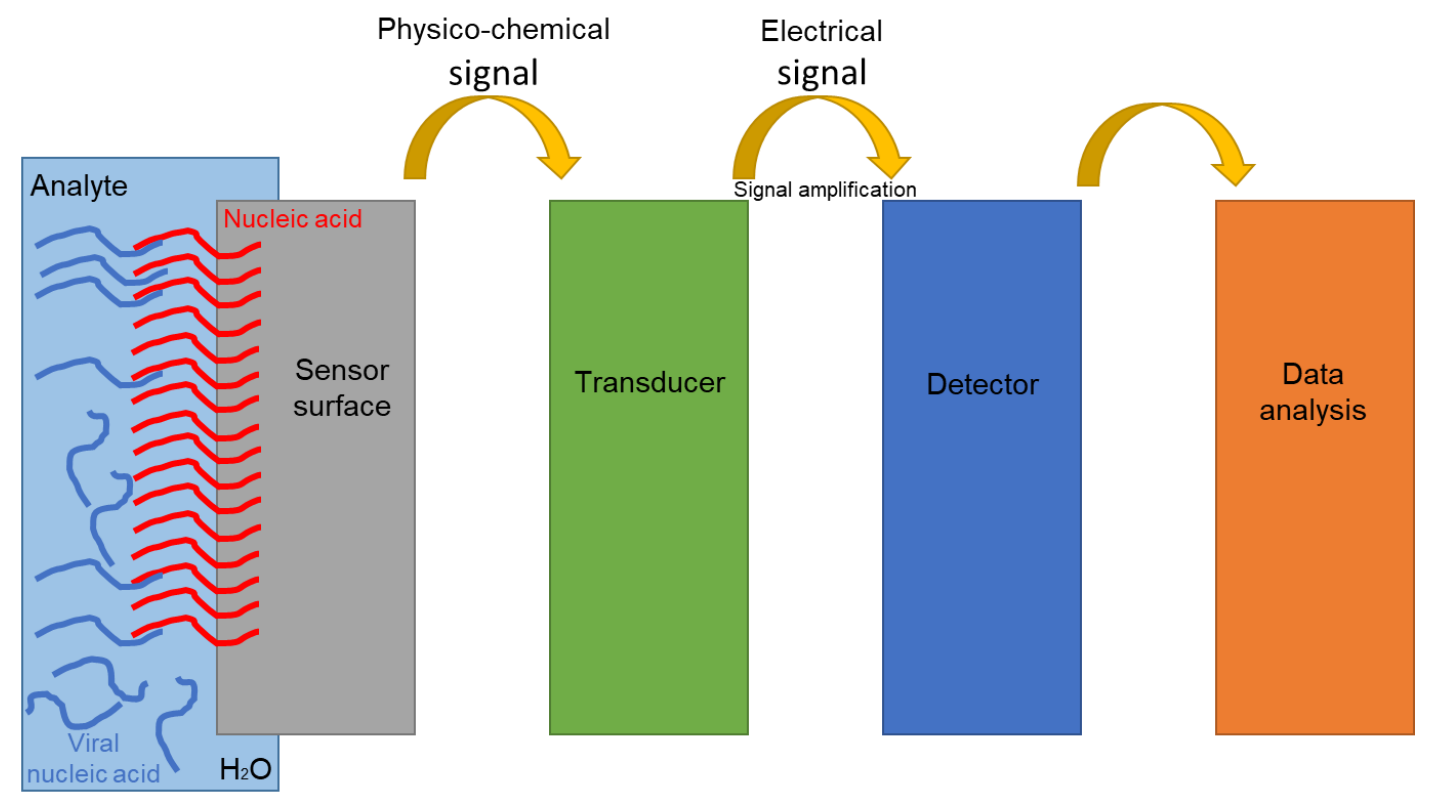

Figure 1 Simplified scheme of biosensor for detection of nucleic acids. Analysed sample reacts with the surface of biosensor (biorecognition element). On the biosensor's surface a specific probe is bound (for example short chain of oligonucleotide). Reaction surface is necessary to modify to avoid non-specific bond of nucleic acid. After hybridisation of nucleic acid, signal (physical or chemical) is transferred via transducer to detector. Measured signal is then mathematically processed.

\section{MATERIAL AND METHODS}

Chemicals. All chemicals used in this study such as $\mathrm{Cd}\left(\mathrm{CH}_{3} \mathrm{COO}\right)_{2} \cdot 2 \mathrm{H}_{2} \mathrm{O}, \mathrm{Na}_{2} \mathrm{TeO}_{3}$, mercaptosuccinic acid (MSA), Trizma base, trisodium citrate, hydrogen tetrachloroaurate(III) ( $\left.\mathrm{HAuCl}_{4}\right)$, DMSO, 3,3',5,5'tetramethylbenzidine (TMB), hydrogen peroxide $\left(\mathrm{H}_{2} \mathrm{O}_{2}\right)$, acetic acid $(\mathrm{HAc})$, sodium acetate $(\mathrm{NaOAc})$, tris $(2$ carboxyethyl)phosphine hydrochloride (TCEP), ethylenediaminetetraacetic acid (EDTA), disodium hydrogen phosphate $\left(\mathrm{Na}_{2} \mathrm{HPO}_{4}\right)$, potassium dihydrogen phosphate $\left(\mathrm{KH}_{2} \mathrm{PO}_{4}\right)$, sodium chloride $(\mathrm{NaCl})$, potassium chloride $(\mathrm{KCl})$, tris(hydroxymethyl)aminomethane (Tris), hydrogen chloride ( $\mathrm{HCl}), \quad \mathrm{KING} \quad \mathrm{F}$ : 5'CTGCTCATGGTATCAATCTTATCGA-3', KING R: 5'-GATACCACAAGATCAGCCGT-3' and HCl were purchased from Sigma-Aldrich (St. Louis, MO, USA), in ACS purity. Propanol and $\mathrm{NaBH}_{4}$ were purchased from Merck (Darmstadt, Germany). All plastic materials used (tubes, tips) in this study were purchased from 
Eppendorf (Hamburg, Germany). Deionised water was prepared by using the reverse osmosis equipment Aqual 25 (Brno, Czech Republic), and was further purified by using an ELGA apparatus equipped with a UV lamp (Lane End, United Kingdom). The resistance was $18 \mathrm{M} \Omega$ and the $\mathrm{pH}$ was measured using the $\mathrm{pH}$ meter (WTW).

Instruments. For absorption spectra, the wavelength was in the range from 200 to $800 \mathrm{~nm}$. For fluorescence spectra, there were an excitation wavelength of $250 \mathrm{~nm}$ and an emission wavelength in the range from 350 to $800 \mathrm{~nm}$ (Varioskan, Thermo Fisher Scientific, USA). The optical properties of nanoparticles were studied by spectral analysis. The absorbance spectra of nanoparticles were recorded within the range of 400 to $800 \mathrm{~nm}$ using a UV-3100PC UV-VIS spectrophotometer (VWR, Germany). Electrochemical measurements were performed with AUTOLAB Analyser connected to VA-Stand 663, using a standard cell with three electrodes. The working electrode was a hanging mercury drop electrode (HMDE) with a drop area of $0.4 \mathrm{~mm}^{2}$. The reference electrode was an $\mathrm{Ag} / \mathrm{AgCl} / 3 \mathrm{M} \mathrm{KCl}$ electrode and the auxiliary electrode was a graphite electrode. The supporting electrolyte containing $0.2 \mathrm{M}$ acetate buffer ( $\mathrm{pH}$ 5.0) was used. AdTSV DPV was conducted via two independent methods for measuring a.) Oligonucleotides/DNA and b.) Cadmium. AdTSV DPV parameters were set as follows: method a.) an initial potential of $0 \mathrm{~V}$, an end potential $-1,7 \mathrm{~V}$, a modulation time $0.05 \mathrm{~s}$, a time interval $1 \mathrm{~s}$, a step $-5 \mathrm{mV} / \mathrm{s}$, a modulation amplitude of $25 \mathrm{mV}$, Eads $=0 \mathrm{~V}$.; method b.) an initial potential of $-1,7 \mathrm{~V}$, an end potential $0,05 \mathrm{~V}$, a modulation time $0.05 \mathrm{~s}$, a time interval $0.5 \mathrm{~s}$, a step $50 \mathrm{mV} / \mathrm{s}$, a modulation amplitude of $25 \mathrm{mV}$, Eads $=-1.2 \mathrm{~V}$. Scan rate in $\mathrm{CV}$ was changed from $0.05 \mathrm{~V} / \mathrm{s}$ to $0.6 \mathrm{~V} / \mathrm{s}$, an initial potential of $0 \mathrm{~V}$, an end potential $-1.85 \mathrm{~V}$. The size distribution (i.e., the hydrodynamic diameter, $\mathrm{DH}$ ) was determined by dynamic light scattering (DLS) using the Zetasizer Nano ZS ZEN3600 (Malvern Instruments, Malvern, UK) with the detection angle of $173^{\circ}$ in optically homogeneous square polystyrene cells. The samples were diluted hundredfold with deionized water. All measurements were performed at $25^{\circ} \mathrm{C}$. Each value was obtained as an average of 5 runs with at least 10 measurements. Version 7.10 of the Zetasizer Software was applied for data evaluation. The particle charge ( $\zeta$-potential) was measured by the microelectrophoretic method using a Malvern Zetasizer Nano ZS ZEN3600 (Malvern Instruments, Malvern, UK). All the measurements were performed at $25^{\circ} \mathrm{C}$ in polycarbonate cuvettes. Each value was obtained as an average of 5 subsequent runs of the instrument with at least 20 measurements.

Synthesis of SPION/Au/NPs. $1.3 \mathrm{~g}$ of $\mathrm{Fe}\left(\mathrm{NO}_{3}\right)_{3} \cdot 9 \mathrm{H}_{2} \mathrm{O}$ was dissolved in $80 \mathrm{~mL}$ of water (18 M 2 ). A quantity of $1.4 \mathrm{~mL} 25 \% \mathrm{NH}_{3}$ was diluted in $8.6 \mathrm{~mL}$ water and $0.2 \mathrm{~g} \mathrm{NaBH}_{4}$ was dissolved in this mixture and, subsequently, the mixture was stirred $\left(300 \mathrm{rpm}, 10 \mathrm{~min}\right.$ at $\left.22^{\circ} \mathrm{C}\right)$. The solution colour turned to dark brown. The mixture was heated to $100{ }^{\circ} \mathrm{C}$ for $2 \mathrm{~h}$ and stirred ( $300 \mathrm{rpm}$, stirring overnight at room temperature). The magnetic particles were separated from the solution via magnet and washed several times in water. The solution of $\mathrm{HAuCl}_{4}$ $(20 \mathrm{~mL}, 1 \mathrm{mM})$ was added to the magnetic particles and stirred $\left(300 \mathrm{rpm} 3 \mathrm{~h}\right.$ at $\left.22^{\circ} \mathrm{C}\right)$. Subsequently, the solution of $\mathrm{C}_{6} \mathrm{H}_{5} \mathrm{Na}_{3} \mathrm{O}_{7} \cdot 2 \mathrm{H}_{2} \mathrm{O}(0.5 \mathrm{~mL}, 0.265 \mathrm{~g} / 10 \mathrm{~mL})$ was added to the mixture and stirred overnight. Finally, the gold SPIONs were separated via magnet and dried $\left(40{ }^{\circ} \mathrm{C}\right)$.

Statistical analysis of data. Experimental work was performed in at least three independent experiments. Each sample in the experiments was analysed at least five times. The obtained data presented in this paper are the average values. No experimental points were excluded from the proposed experimental study. All the obtained data were stored in the Qinslab database. If possible, data were processed and evaluated mathematically and statistically in the Qinslab database. The results were expressed as mean \pm standard deviation (SD).

\section{RESULTS AND DISCUSSION}

In our suggested biosensor for detection of ASFV, the hybridisation between nucleic acids with oligonucleotide probe labelled with electroactive mark (metals, metal oxides, enzymes, quantum dots, nanoparticles) is used [16-19]. Quantum dots (QDs) have very good properties for electrochemical detection. Their surface can be modified with different molecules and thus it is possible to use them as biosensors. Furthermore, it is possible to prepare different types of QDs, which can provide several measurable signals. Each signal can be used for 
recognition of specific sequence of nucleic acids (details are published in paper Banáš et. al.) [15]. Whole detection system can be enclosed into 3D-print prepared simple electronic microchip. Sample is injected into microchip. In reservoir inside the chip, DNA of ASFV virus is hybridised with QDs-labelled oligonucleotide probe. Electrochemical signal, which is responsible for the confirmation or the rejection of the presence of searched DNA, is perceived by connected electrode [20].

Oligonucleotide probes KING R and KING F complementary to PCR fragment (280 bp) were analysed. The calibration curves from 0.4 to $1.7 \mu \mathrm{g} / \mathrm{mL}$ for $\mathrm{KING} F$ and from 0.1 to $0.6 \mu \mathrm{g} / \mathrm{mL}$ for $\mathrm{KING} \mathrm{R}$ and from 1 to $10 \mu \mathrm{g} / \mathrm{mL}$ for PCR fragment were measured. When the intensities of signals for oligonucleotides and PCR fragment are compared, the best sensitivity was calculated for PCR fragment ( $50 \mathrm{nA} / \mathrm{amol}$ molecules $/ \mathrm{min})$ then KING R ( $25 \mathrm{nA} / \mathrm{amol}$ molecules/min) and finally KING F (14 nA/amol molecules/min). When only ODNs were accumulated on $\mathrm{Hg}$ electrode, the signals of cytosine and adenine (CA signal) in potential about $-1.3 \mathrm{~V}$ [3] (Hg against $\mathrm{Ag} / \mathrm{AgCl} / 3 \mathrm{M} \mathrm{KCl}$ ) were $33 \pm 8 \mathrm{nA}$ for King $\mathrm{F}$ and $22 \pm 3 \mathrm{nA}$ for KING R (3 minutes; $1.0 \mu \mathrm{g} / \mathrm{mL}$ King $\mathrm{F}$ and $0.3 \mu \mathrm{g} / \mathrm{mL}$ King R; 10 measurements). For interaction ODNs and CdTe, CA signals were detected as follows: KING F/QDs $15 \pm 8 \mathrm{nA}$, KING R/QDs $16 \pm 5 \mathrm{nA}$ and cadmium ions signals were detected as follows: KING F/QDs $61 \pm 15 \mathrm{nA}$ and KING R/QDs $89 \pm 18 \mathrm{nA}$. Successful verification of interaction was proved by measurement of signal of cadmium ion and lower signals of oligonucleotides in interaction complex, because of lowered sensitivity of nucleotides when bound with CdTe QDs.

To evaluate, how ASFV PCR fragment is accumulated on electrode surface, dependences of signal of CA peak and $P$ peak on time of accumulation $(30 ; 60 ; 120 ; 240 ; 480$ a $720 \mathrm{~s})$ were measured. Scan rate was 0.25 $\mathrm{V} / \mathrm{s}$. Dependence for CA peak was linear $(23.6525+0,1687 \mathrm{x} ; r=0.99509)$, dependence for $P$ peak was slightly hyperbolic $\left(-229.2775+7.1954 x-0.0048 x^{2} ; r=0.99433\right)$ and therefore $2^{\text {nd }}$ degree polynomic curve was calculated for characterisation of behaviour of peak. Dependence of peak height on time of accumulation of DNA on Au-SPION nanoparticles was measured. Accumulation was conducted in standard conditions in phosphate buffer $(\mathrm{c}=0.1 \mathrm{M}, \mathrm{pH}=7)$. Times of accumulation were $15,30,60,90$ and $120 \mathrm{~s}$. Strongest signal was $504 \mathrm{nA}$ in $30 \mathrm{~s}$. With increasing time of accumulation, the signal was slightly reduced (around $400 \mathrm{nA}$ ), when time was only 15 seconds, only $10 \mathrm{nA}$ signal was measured.
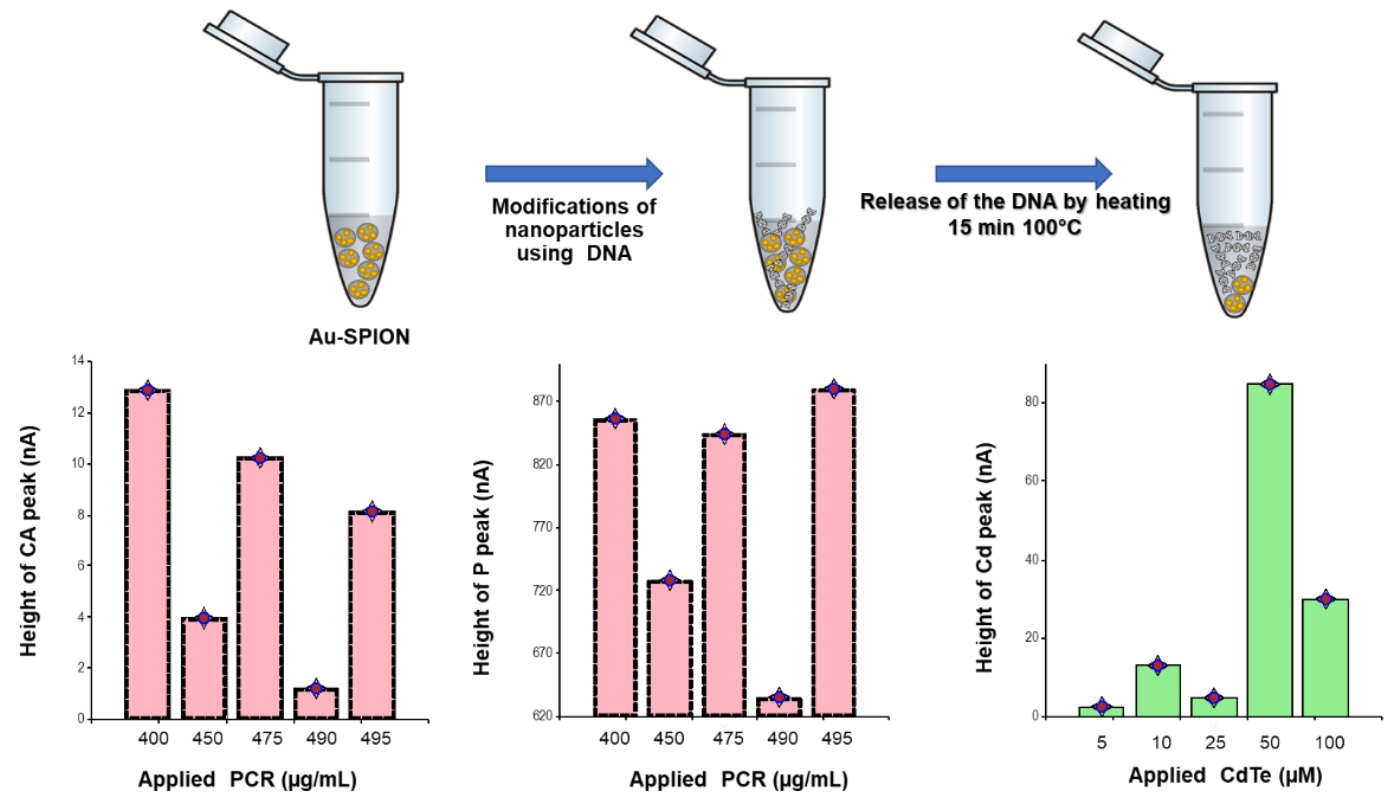

Figure 2 Comparison of CA, P a Cd signals after binding of nucleic acid on SPION (30 min interaction) and CdTe. After interaction, 3 wash steps were conducted with PBS. Measurement was conducted in acetate buffer, $0,2 \mathrm{M}, \mathrm{pH} 5$, tA $120 \mathrm{~s}$. AdTSV DPV: scan rate $5 \mathrm{mV} / \mathrm{s}$, starting potential $0 \mathrm{~V}$, terminating potential -1.8 $\mathrm{V}, \mathrm{n}=2$. Data are statistically showed as box plots for current response and potential of signal. 
SPION nanoparticles are used, because of the two properties for their surface (separation and detection). The ability of SPION nanoparticles to catch PCR/DNA, especially ASFV PCR fragment (DPV AdTSV $25 \mathrm{mV} / \mathrm{s}$, drop $10 \mu \mathrm{L}, 120 \mathrm{~s})$ was tested (Figure 2). RSD of detection of DNA was $16,25 \%(\mathrm{n}=44)$, concentration dependence $(0-6 \mu \mathrm{g} / \mathrm{mL})$ was linear $(\mathrm{y}=8,63 \mathrm{x})$. PCR/DNA $(100 \mu \mathrm{g} / \mathrm{mL})$ was mixed with SPION nanoparticles $(1 \mathrm{mg} / \mathrm{mL})$. Interaction was conducted 30 minutes, $300 \mathrm{rpm}, 25^{\circ} \mathrm{C}$, phosphate buffer $\mathrm{pH}$ 7. Non-specific bound PCR/DNA was washed ( 3 times, $500 \mu \mathrm{l}$ of phosphate buffer, $\mathrm{pH} 7,300 \mathrm{rpm}, 25^{\circ} \mathrm{C}$ ). Specific bound PCR/DNA was thermally released from SPION $\left(50 \mu \mathrm{L}\right.$, phosphate $\left.\mathrm{pH} 7,350 \mathrm{rpm}, 99^{\circ} \mathrm{C}, 15 \mathrm{~min}\right)$. Average CA signals $(-1,30$ $\mathrm{V})$ of caught PCR/DNA were $7.2 \pm 5,8 \mathrm{Cl} n A(n=5)$ with the DNA recovery about $10 \%$. Sensitivity and selectivity of determination was quite good, but our aim was to improve sensitivity more. Therefore, $P$ peak as a catalytic signal was studied. Using $P$ peak instead of CA peak make the sensitivity 15 times higher than using CA peak. Furthermore, variability of analysis was lowered to $16 \%$. Besides above-mentioned analysis, different types of modification in the term of reaction volume were tested for the maximization of electrochemical response. Steps of hybridisation on SPION nanoparticles were conducted with effectiveness about $5 \%$. Different shapes and sizes of 3D chips were suggested, and their properties were tested.

\section{CONCLUSION}

Many experimental manuscripts were published about electrochemical behaviour of nucleic acids [19]. However, about interactions of oligonucleotides with quantum dots, there is a lack of available data [21]. This work was based on basic electrochemical behaviour of ODN and ODN/QDs. Different behaviour of oligonucleotides King $F$ and King $R$ was found out on HDME. Furthermore, we prove differences in signals of ODN (Ip, Ep) when interact with QDs. From these results, it can be concluded that these changes in structure can significantly influence electrochemical behaviour and must be accounted, when experimental data are interpreted. Besides this fact, this knowledge can be useful for suggestion of new types of biosensors [22,23]. Isolation of DNA from biological material is necessary for its detection. Early diagnosis of highly infectious pathogens is key to taking anti-epidemic measures. Modified SPION nanoparticles are suitable surface for detection and separation.

\section{ACKNOWLEDGEMENTS}

\section{The study was supported by the EU programme for education, training, youth, and sport Erasmus+, NANOVIR JCMM 277/2020 and project AMOR QK1920113.}

\section{REFERENCES}

[1] YORK, A. Novel coronavirus takes flight from bats? Nature Reviews Microbiology. 2020, vol. 18, p. 191.

[2] WANG, N., ZHAO, D. M., WANG, J. L., ZHANG, Y. L., WANG, M., GAO, Y., LI, F., WANG, J. F., BU, Z. G., RAO, Z. H.,WANG, X. X. Architecture of African swine fever virus and implications for viral assembly. Science. 2019, vol. 366, no. 6465, pp. 640-644.

[3] WANG, N., ZHAO, D., WANG, J., ZHANG, Y., WANG, M., GAO, Y., LI, F., WANG, J., BU, Z., RAO, Z., WANG, X. Architecture of African swine fever virus and implications for viral assembly. Science. 2019, vol. 366, no. 6465, pp. 640-644.

[4] KRZYZANKOVA, M., KRASNA, M., BENA, M.,VASICKOVA, P. Virus afrického moru prasat a možnosti jeho šíření masem a masnými výrobky. Maso. 2020, vol. 1, no. 2020, pp. 32-38.

[5] GOGIN, A., GERASIMOV, V., MALOGOLOVKIN, A.,KOLBASOV, D. African swine fever in the North Caucasus region and the Russian Federation in years 2007-2012. Virus Res. 2013, vol. 173, no. 1, pp. 198-203.

[6] ZHOU, X. T., LI, N., LUO, Y. Z., LIU, Y., MIAO, F. M., CHEN, T., ZHANG, S. F., CAO, P. L., LI, X. D., TIAN, K. G., QIU, H. J.,HU, R. L. Emergence of African Swine Fever in China, 2018. Transbound. Emerg. Dis. 2018, vol. 65, no. 6, pp. 1482-1484.

[7] CAPUA, I.,MONTI, M. African swine fever could splinter the EU. Nature. 2019, vol. 566, no. 7744, pp. 326-326. 
[8] GARIGLIANY, M., DESMECHT, D., TIGNON, M., CASSART, D., LESENFANT, C., PATERNOSTRE, J., VOLPE, R., CAY, A. B., VAN DEN BERG, T.,LINDEN, A. Phylogeographic Analysis of African Swine Fever Virus, Western Europe, 2018. Emerg. Infect. Dis. 2019, vol. 25, no. 1, pp. 184-186.

[9] KUCINSKY, P. Aficky mor prasat. Veterinarstvi. 2020, vol. 70, no. 8, pp. 475-478.

[10] PALECEK, E., JELEN, F. Electrochemistry of nucleic acids and development of DNA sensors. Critical Reviews in Analytical Chemistry. 2002, vol. 32, no. 3, pp. 261-270.

[11] THEVENOT, D. R., TOTH, K., DURST, R. A.,WILSON, G. S. Electrochemical biosensors: recommended definitions and classification. Biosensors \& Bioelectronics. 2001, vol. 16, no. 1-2, pp. 121-131.

[12] PALECEK, E., POSTBIEGLOVA, I. Adsorptive stripping voltammetry of biomacromolecules with transfer of the adsorbed layer. Journal of Electroanalytical Chemistry. 1986, vol. 214, no. 1-2, pp. 359-371.

[13] PALECEK, E. New trends in electrochemical analysis of nucleic-acids. Bioelectrochemistry and Bioenergetics. 1988, vol. 20, no. 1-3, pp. 179-194.

[14] PALECEK, E., FOJTA, M. Detecting DNA hybridization and damage. Analytical Chemistry. 2001, vol. 73, no. 3, pp. 74A-83A.

[15] BANAS, D., AKSU, D. A., NOGUERA, V. M., MERT, P., HOSNEDLOVA, B.,KIZEK, R. Elektrochemická studie oligonukletidových sond značených kvantovými tečkami pro detekci nukleové kyseliny viru afrického moru prasat. Chem. Listy. 2020, vol. 101, pp. 1-6.

[16] MILLS, D. M., FOGUEL, M. V., MARTIN, C. P., TRIEU, T. T., KAMAR, O., CALVO-MARZAL, P., KOLPASHCHIKOV, D. M.,CHUMBIMUNI-TORRES, K. Y. Rapid detection of different DNA analytes using a single electrochemical sensor. Sens. Actuator B-Chem. 2019, vol. 293, pp. 11-15.

[17] KOKKINOS, C. T., GIOKAS, D. L., ECONOMOU, A. S., PETROU, P. S.,KAKABAKOS, S. E. Paper-Based Microfluidic Device with Integrated Sputtered Electrodes for Stripping Voltammetric Determination of DNA via Quantum Dot Labeling. Anal. Chem. 2018, vol. 90, no. 2, pp. 1092-1097.

[18] POLSKY, R., HARPER, J. C.,BROZIK, S. M. Nanomaterial-Based Electrochemical DNA Detection. In: Electrochemical DNA Biosensors. Singapore: Pan Stanford Publishing Pte Ltd., 2012, pp. 427-465.

[19] DRUMMOND, T. G., HILL, M. G.,BARTON, J. K. Electrochemical DNA sensors. Nat. Biotechnol. 2003, vol. 21, no. 10 , pp. 1192-1199.

[20] GARGULAK, M., SEHNAL, K., HOSNDLOVA, B., HOAI, N., DOCEKALOVA, M., OFOMAJA, A., STANKOVA, M., UHLIROVA, D., KEPINSKA, M., MILNEROWICZ, H., FERNANDEZ, C., VACIKOVA, P.,KIZEK, R. 3D-printed CdTe QDs-based sensor for sensitive electrochemical detection of viral particles. In: IEEE International Conference on Sensors and Nanotechnology. Penang, Malaysia, 2019, pp. 1-6.

[21] BOUSSICAULT, F., ROBERT, M. Electron transfer in DNA and in DNA-related biological processes. Electrochemical insights. Chem. Rev. 2008, vol. 108, no. 7, pp. 2622-2645.

[22] SIRIWONG, K., VOITYUK, A. A. Electron transfer in DNA. Wiley Interdiscip. Rev.-Comput. Mol. Sci. 2012, vol. 2, no. 5, pp. 780-794.

[23] KELLEY, S. O.,BARTON, J. K. Electron transfer between bases in double helical DNA. Science. 1999, vol. 283, no. 5400 , pp. $375-381$. 